\title{
Effect of Paddy Straw and Rice Husk Mulching on Soil Microbial Population in Acid Lime (Citrus aurantifolia Swingle)
}

\author{
Esther Lalruatsangi* and BN Hazarika and P Raja \\ Department of Fruit Science, Central Agricultural University, India
}

Submission: November 10, 2018; Published: December 14, 2018

*Corresponding author: Esther Lalruatsangi, Department of Fruit Science, College of Horticulture and Forestry, Central Agricultural University, Pasighat, Arunachal Pradesh, India

\begin{abstract}
An experiment was conducted to study the effects of paddy straw and rice husk mulching on acid lime during 2014-2015 in Randomized Block Design compared with control (without mulch). The study revealed that the microbial population of the soil was found to be highly significant. The higher microbial population count for bacteria was observed in paddy straw mulch $\left(83.45 \times 10^{5} \mathrm{cfu} / \mathrm{g}\right)$ as compared to rice husk mulch $\left(74.88 \times 10^{5}\right.$ $\mathrm{cfu} / \mathrm{g})$ while minimum was found in control $\left(14.06 \times 10^{5} \mathrm{cfu} / \mathrm{g}\right)$. Likewise, the highest microbial population count for fungi was observed in rice husk mulch $\left(119.34 \times 10^{5} \mathrm{cfu} / \mathrm{g}\right)$ as compared to paddy straw mulch $\left(54.77 \times 10^{5} \mathrm{cfu} / \mathrm{g}\right)$ while no microbial growth of fungi was observed under control (no mulch).
\end{abstract}

Keywords: Acid lime; Mulching; soil; Bacteria; Fumgi; Paddy straw mulch; Banana leaf; Plants; Grass clippings; wood chips; Quality of soil; Crop yields; Carbon; Bacteria; Fungi

\section{Mini Review}

Mulching plays an important role in conservation of soil moisture during dry periods, as well asimproves physical, biological and chemical properties of soil). A mulch is a material placed on or spread over the soil surface to protect the soil from erosion, conserve soil moisture and suppress weed growth. Mulching is a practice, which helps in proper growth and development of the plants by modifying soil temperature, providing better nutrient availability and by better moisture conservation [1,2]. Materials commonly used for mulch which are organic include banana leaf, grass clippings, wood chips or bark, etc. There are reports on the effect of mulching on improving microbiological quality of soil and crop yields $[1,3,4]$.

The organic mulch such as paddy straw and rice husk are rich in carbon content in which microbial population is very high. The microbial population from the soil are mostly bacteria and fungi. However, the advantageous effects of the mulching materials have not been studied in acid lime orchard. The experimental study focused on analysis of soil microorganisms by various mulching treatments as compared with average fruit yield in acid lime orchard. The data was analyzed statistically with the help of analysis of variance. The study was conducted during 2014-2015 in 6 years old acid lime orchard planted at a spacing of $3 \mathrm{~m} \times 3 \mathrm{~m}$. The experiment was laid out in Randomized Block Design (RBD) with three [3] replications and three [3] treatments with 3 plants in each treatment.
The organic mulching treatments used for the study are Paddy Straw (6 $\mathrm{cm}$ thickness) and Rice Husk (6 $\mathrm{cm}$ thickness) as compared to control (without mulch). The microbial analysis of the soil was evaluated after harvesting of fruits. The analysis of soil has revealed that the microbial population of the soil was found to be highly significant. The higher microbial population count for bacteria was observed in paddy straw mulch $(83.45 \times$ $\left.10^{5} \mathrm{cfu} / \mathrm{g}\right)$ as compared to rice husk mulch $\left(74.88 \times 10^{5} \mathrm{cfu} / \mathrm{g}\right)$ while minimum was found in control $\left(14.06 \times 10^{5} \mathrm{cfu} / \mathrm{g}\right)$. Likewise, the highest microbial population count for fungi was observed in rice husk mulch $\left(119.34 \times 10^{5} \mathrm{cfu} / \mathrm{g}\right)$ as compared to paddy straw mulch $\left(54.77 \times 10^{5} \mathrm{cfu} / \mathrm{g}\right)$ while no microbial growth of fungi was observed under control (no mulch). The data is presented in (Table 1).

Table 1: Effect of paddy straw and rice husk mulching on microbial population.

\begin{tabular}{|c|c|c|}
\hline Treatments & Bacteria $\left(\times \mathbf{1 0}^{\mathbf{5}}\right)$ & Fungi $\left(\mathbf{x 1 0} \mathbf{5}^{\mathbf{5}}\right)$ \\
\hline Control (without mulch) & 14.06 & 0 \\
\hline Paddy straw & 83.45 & 54.77 \\
\hline Rice husk & 74.88 & 119.34 \\
\hline
\end{tabular}

\section{References}

1. Gargi N, Singh G, Yadav P, Goel N, Soni MK (2007) Effect of mulching on soil microbial population in guava (Psidium guaiava) orchard soil. Indian Journal of Agricultural Sciences 77(4): 241-243. 
2. Kher R, Baba JA, Bakshi $P$ (2010) Influence of planting time and mulching material on growth and fruit yield of strawberry cv. Chandler Indian Journal of Horticulture 67(4): 441-444.

3. Ogban PI, Ekanem TP, Etim EA (2001) Eflect of mulching methods on soil properties and growth and yield of maize in South-Eastern Nigeria Tropical Agriculture 78 (2): 82-89.

his work is licensed under Creative

Commons Attribution 4.0 Licens

DOI: 10.19080/AIBM.2018.12.555827
4. Varga C, Buban T, Piskolczi M (2004) Effect of organic mulching on the quantity of microorganisms in soil of apple plantation. Journal of Fruit and Ornamental Plant Research 12: 147-155.

\section{Your next submission with Juniper Publishers will reach you the below assets}

- Quality Editorial service

- Swift Peer Review

- Reprints availability

- E-prints Service

- Manuscript Podcast for convenient understanding

- Global attainment for your research

- Manuscript accessibility in different formats

( Pdf, E-pub, Full Text, Audio)

- Unceasing customer service

Track the below URL for one-step submission https://juniperpublishers.com/online-submission.php 